This item was submitted to Loughborough's Research Repository by the author.

Items in Figshare are protected by copyright, with all rights reserved, unless otherwise indicated.

\title{
‘Broadcast to mark Holocaust Memorial Day’: Mass mediated Holocaust commemoration on British television and radio
}

PLEASE CITE THE PUBLISHED VERSION

https://doi.org/10.1177/0267323118763919

\section{PUBLISHER}

(C) The authors. Published by SAGE Publications Ltd

\section{VERSION}

AM (Accepted Manuscript)

\section{PUBLISHER STATEMENT}

This work is made available according to the conditions of the Creative Commons Attribution-NonCommercialNoDerivatives 4.0 International (CC BY-NC-ND 4.0) licence. Full details of this licence are available at: https://creativecommons.org/licenses/by-nc-nd/4.0/

\section{LICENCE}

CC BY-NC-ND 4.0

\section{REPOSITORY RECORD}

Richardson, John E.. 2019. “'broadcast to Mark Holocaust Memorial Day': Mass Mediated Holocaust Commemoration on British Television and Radio". figshare. https://hdl.handle.net/2134/28374. 
'Broadcast to mark Holocaust Memorial Day': Mass mediated Holocaust commemoration on British television and radio

John E Richardson

Loughborough University

Contact Details

John E Richardson

Department of Social Sciences,

Loughborough University

Epinal Way,

Loughborough, Leicestershire,

LE11 3TU, UK

j.e.richardson@lboro.ac.uk

$+44(0) 1509223361$

Biog

John E Richardson is a Reader in Critical Discourse Studies, Department of Social Sciences, Loughborough University. His research interests include structured social inequalities, British fascism, argumentation and multimodal commemoration. His most recent book is British Fascism: A Discourse-Historic Analysis (Stuttgart: ibidem Verlag, 2017). He is Editor of the international journal Critical Discourse Studies and co-editor of Bloomsbury book series Advances in Critical Discourse Studies. From February 2017-January 2018 he was a 
Leverhulme Trust Research Fellow, researching the ways that Holocaust Memorial Day in the UK has changed since 2002.

\section{Abstract}

This article examines the various programmes that British television and radio broadcast to mark Holocaust Memorial Day (HMD), between 2002 and 2016. Adopting a content analytic methodology, I quantified the broadcast schedules of 15 successive HMDs, as recorded in archived copies of the Radio Times. My analysis reveals significant variations in mass-mediated Holocaust commemoration. Principally, I found: a decrease in programming, despite a significant increase in the number of television channels; a tendency towards 'anniversarism' in the form and frequency of broadcast programmes; a stress on Auschwitz, as metonym of the Holocaust, and on survivors, children and music; and that commercial channels were significantly more likely to broadcast documentaries (and repeats) than the $\mathrm{BBC}^{\prime}$ 's more varied and original outputs. These variations appear to be the result of three interlinked factors: first, a sense that the audience had grown weary of World War II commemoration, following saturation broadcasting of anniversaries in 2004-2005; changes in the management and programming priorities of key broadcasters, particularly the BBC; and that HMD has not yet become an established day for broadcasters in the nation's commemorative calendar.

\section{Key words}

Broadcasting, Television, Radio, Holocaust Memorial Day, Commemoration, Content Analysis

\section{Introduction}


The mass media, whether television, radio, feature films, the press and various websites on the internet, constitute the most significant sites for the representation and consumption of historical narratives in modern societies (de Groot 2016; Zelizer 1992). Public awareness and understanding of the Holocaust - what Pearce (2014) calls Holocaust consciousness - has developed hand in hand with its mass mediation, whether through fictional or actuality genres. However, questions remain regarding "the ability of popular broadcast media to produce meaningful, valid and engaging representations of difficult pasts, and especially of the Holocaust" (Meyers et al 2014: 103). Whilst Gray and Bell (2013: 219) point out that "it is certainly not impossible to create and broadcast commercially successful factual history programming", they also quote a BBC Strategy Document (2009) which recognised "The key challenge for BBC History is to balance entertainment and information in the right proportions for a range of different audiences" (p.160).

The first British Holocaust Memorial Day (HMD) took place January 27 2001. The decision to initiate a British HMD was taken in the Stockholm International Forum in 2000, at the end of which representatives from 46 governments around the world signed a declaration committing to preserve the memory of those who have been murdered in the Holocaust (Allwork 2015). The 2001 national HMD ceremony was held in Westminster Central Hall and televised live on the BBC to around 1.5 million viewers. A capacity audience of 2,000 people were present in the Hall, including leaders of the three main political parties, cultural figures, 200 Holocaust survivors and representatives of the wider Jewish communities; Prime Minister Tony Blair gave the keynote speech. In 2005, the Holocaust Memorial Day Trust (HMDT) took over responsibility for organising HMD from the government.

The contents and staging of the first national HMD ceremony have also been written about in detail (Macdonald 2005; Pearce 2013, 2014; Sauer 2012), but in contrast, there is a surprising lack of analysis of HMD commemoration since 2002 (though see Richardson 2017, 2018a; Eadson et al 2015). Academic analysis of the mass mediation of Holocaust commemoration is even thinner, aside 
from a series of ground-breaking studies by Meyers, Neiger and Zandberg on Holocaust commemoration in Israeli mass media (though see Richardson 2018b; also Gray and Bell 2013). This article aims to start to address this absence, by examining the various programmes that British television and radio broadcast to mark HMD. Adopting a content analytic methodology, I quantified the broadcast schedules of 15 successive HMDs, as recorded in archived copies of the Radio Times. My results reveal significant variations in the form and frequency of mass-mediated Holocaust commemoration.

\section{Literature Review}

Analysis of the ways that the mass media contribute to shaping public knowledge and understanding of the past has expanded significantly in recent years (Neiger et al 2011b; Zelizer 1992). Television broadcasters, in particular, ${ }^{1}$ are said to "provide a public arena for various agents [...] who want to influence the ways in which collective pasts are narrated and understood" (Meyers et al 2014: 5; see also Dillon 2010; Edgerton \& Rollins 2001). And, although questions regarding the (in)ability of the mass media to do 'proper history' remain a perennial feature (cf Kershaw 2004), Bell and Gray (2007) suggest that an "increasing number of historians do recognise the value of this form of public communication in disseminating historical knowledge" (p.144).

The Holocaust has become a fixture of Western culture (Marrus 2015; Pearce 2014) and, as such, is the frequent focus of mass media broadcasts. However, just as the Holocaust exposes the limits of evidence and representation in historiography (Stone 2012), so too "the extreme nature of the Holocaust clearly illuminates both the limitations and the capabilities of commercial media in its representation of a difficult past" (Meyers et al 2014: 5). Criticism of Holocaust broadcasting tends to take one of three forms, all of which question the limits of representation. First, at the most fundamental level, there is the question whether any televisual representation of the Holocaust constitute misrepresentations, given that "the medium cannot convey the physical - and, therefore, 
the metaphysical - ugliness of the subject" (Shandler 1999: 168). Such a criticism, however, must necessarily include any and all historiography of the Holocaust, given that it too is (only) a representation of the past and so ostensibly incapable of conveying its metaphysical ugliness.

Second, "the incursion of commercial culture into most forms of cultural production" (Meyers et al 2009: 459) is assumed to mitigate against rigorous examination of the Holocaust through its pursuit of a mass audience. Such "media contents strive to attract a superficial kind of attention, and their main quality is that they do not challenge the consumer" (Meyers et al 2014: 6). Accordingly, to appeal to a popular/mass market of viewers, the desperate moral challenges of the Holocaust, as one of the foundational events of our age, are "cut down to size" and rendered "commonplace instead of awesome and frightening" (Mosse, cited in Marrus 2015: 16).

Third, and following on from this second point, "in order to please consumers, media products are designed according to schemes that have been proven to be successful in the past" (emphasis added, Meyers et al 2014: 6). Corner (1999: 93) argues that "giving of pleasure is the primary imperative of most television production" and, in the case of factual programming, this is derived from balancing "the pleasures which gaining knowledge involves" (Corner 1999: 96) with the pleasure of consuming narratives structured in accordance with conventional schemes and tropes. As Smither (2004: 51) put it, "the best guarantee that a project will make you money, or at least will not lose you money, is to ensure that it conforms closely to the pattern of something that has visibly worked before." Cole (2000) argues that in popular/mass mediated Holocaust historiography, stories of survival are frequent, as are active heroes and rescuers - particularly those from 'Our nation' and definitive 'happy endings' which "skirt the horrors of the Holocaust and offer us something much more palatable in its place" (p.xvii). In sum, the reception and criticism of mass mediated representation of the Holocaust suggest "that aesthetically appropriate mediations (e.g. documentary film) and venues (non-commercial television) for the presentation of the Holocaust do 
exist, but what distinguishes them as appropriate, dignified or serious also disqualifies them from effectively reaching mass audiences" (Shandler 1999: 171).

That said, Kansteiner (2008: 154) maintains that "public negotiations about national and other identities have been increasingly conducted through narrative visual media, especially film and television" and that film and TV about the Holocaust has played "an important role" in this (see also Kansteiner 2006). The broadcast of the TV drama series Holocaust is usually identified as representing "a key turning point towards, perhaps even the first example of, the development of a popular transnational memory of the Holocaust" (Kansteiner 2008: 166), particularly in the Federal Republic of Germany. In Britain, meanwhile, Kansteiner argues that "Holocaust themes surfaced with some delay and never became a popular staple of mass entertainment. [...] It is tempting to attribute this lack of an indigenous Holocaust culture to the fact that the British, in contrast to many other European nations, never had to endure occupation and deportation at the hands of the Nazis" (p. 168). This explanation, drawing as it does on a phlegmatic version of the Churchillian narrative of British resistance, is a common place in historiography. ${ }^{2}$ However, it is also incorrect; a region of Britain was occupied, from June 1940 until the end of the War - the Channel Islands - and citizens of the islands were deported to camps on mainland Europe. More specifically, the remaining Jewish citizens and residents of the Islands were deported to Auschwitz, where they were murdered, and their property subsequently 'aryanised' (Fraser 2000).

Such insights draw our attention to the ways that the depiction of the nation in history broadcasting relates to the social and political life of the nation in the present - both in terms of national "power structures and hierarchies maintained or rejected by such narratives of the past" (Gray \& Bell 2013: 7), and the ways that broadcasting (sometimes constructing) rituals and traditions contributes to the rhythm of the nation across a calendar year (see also Scannell \& Cardiff 1991). Gray and Bell (2013) argue that "anniversaries of key events are particularly sensitive in terms of national identity maintenance and this may be seen in UK television" (p.20) as much as in other countries. Indeed, in 
their chapter on commemorative television, they argue that nowhere is the representation of the nation (and its relation to gender, social class, ethnicity and race) "more significant than in commemorative programming, which seeks to represent a historical national identity, and in so doing, to create a sense of community within a culturally disparate nation" (p.100). Whilst Chapman (2007) highlights the subversive potential of some commemorative programming there is, as Young (1999: 86) points out, a danger "of turning Holocaust memory into a kind of self-congratulatory spectacle", ignoring controversial periods of British Holocaust history.

\section{Methods}

This article is drawn from a wider project aimed at analysing linguistic and semiotic processes employed in the commemoration of HMD, their potential for shaping the understanding of mass audiences and the ways that the commemoration of HMD has changed since 2002. My research triangulates data and methods in order to make sense of both the field of remembrance and its genres (e.g. ceremonies, speeches, stories, testimony, music, minutes of silence, etc.) and the ways that they reflect the complex interplay between historiography, popular understandings of history, and social and historic contexts. This article offers a quantitative content analysis of television and radio programming, over a 15 year period, in order to examine patterns in mass mediated HMD commemoration. My choice of data and method are quite novel - as Meyers et al (2009: 458) point out, "The vast majority of collective memory studies rely on qualitative methods, and when quantitative methods are used, it is mostly to survey the public rather than to explore mnemonic contents" (cf Bennett 2006; Piccini 2007). My content analysis used archived copies of the Radio Times, published between 2002 and 2016, and quantified the frequency and form of programming broadcast on British television and radio to mark HMD. Writers such as Jacobs (2000) and Holmes (2005) have also demonstrated the efficacy of such an approach to broadcasting history, when the audio-visual archive is either non-existent or, in my case, incomplete. 
Programmes which mark HMD are not only broadcast on the 27 January itself, but are also transmitted either side of the day, to fit with the normal programming week. ${ }^{3}$ Accordingly, I sampled seven continuous days of broadcasting each year, either side of HMD in addition to HMD itself, to capture these variations in scheduling (see Ellis 2000).

A programme listing qualified for analysis if:

(1) it fell within the week of HMD

and it mentioned (2) 'The Holocaust' in either the title or the description, or (3) a widely recognized metonym for the Holocaust (e.g. any concentration or death camp) or (4) that the Radio Times specifically stated that it was broadcast 'to mark' or 'on' HMD. This procedure was adopted to allow me to distinguish between programming intended to commemorate HMD and the preoccupation with WWII that one frequently sees with British television, particularly on history channels. Only full programmes qualified for analysis, unless Radio Times explicitly stated that a (e.g. magazine) programme was broadcast to mark HMD. This was to distinguish between specifically commemorative texts and other actuality genres (e.g. coverage of HMD on the news).

There was one type of text that stepped slightly outside of my sampling procedure: Thought for the Day, broadcast on Radio 4, doesn't give any indication of its contents in the Radio Times listing, only the name of the presenter. Late in the sample, the Chief Rabbi Ephraim Mirvis delivered the Radio 4 Thought for the Day on the morning of several Holocaust Memorial Days. The transcripts of these broadcasts on the Radio4 website shows that they did indeed commemorate the Holocaust, so they were included in the sample. I then went back and re-included earlier 'Thoughts for the Day' spoken by the previous Chief Rabbi Jonathan Sacks, including one broadcast on 26 Jan 2007, given that it is most likely that the Chief Rabbi would have also been reflecting on the annual HMD. 
I initially photographed all qualifying programmes in the Radio Times. This allowed me to maximise my time in the archive as well as giving me a sense of the sample as a whole. I then developed a coding manual of 20 variables, to apply to the programme titles and descriptions, to quantify their contents. The results were analysed using the statistics programme SPSS.

\section{Results}

Frequency and length of programmes

Across the 15 years of sampled issues of Radio Times, there were 150 items broadcast on British TV and radio to mark HMD - an average of 10 per year. Graphs 1 and 2, below, show how these programmes were distributed across the sample period, the first showing number of programmes and the second showing the total minutes broadcast each year. 
Graph 1: Frequency of programmes broadcast to mark HMD

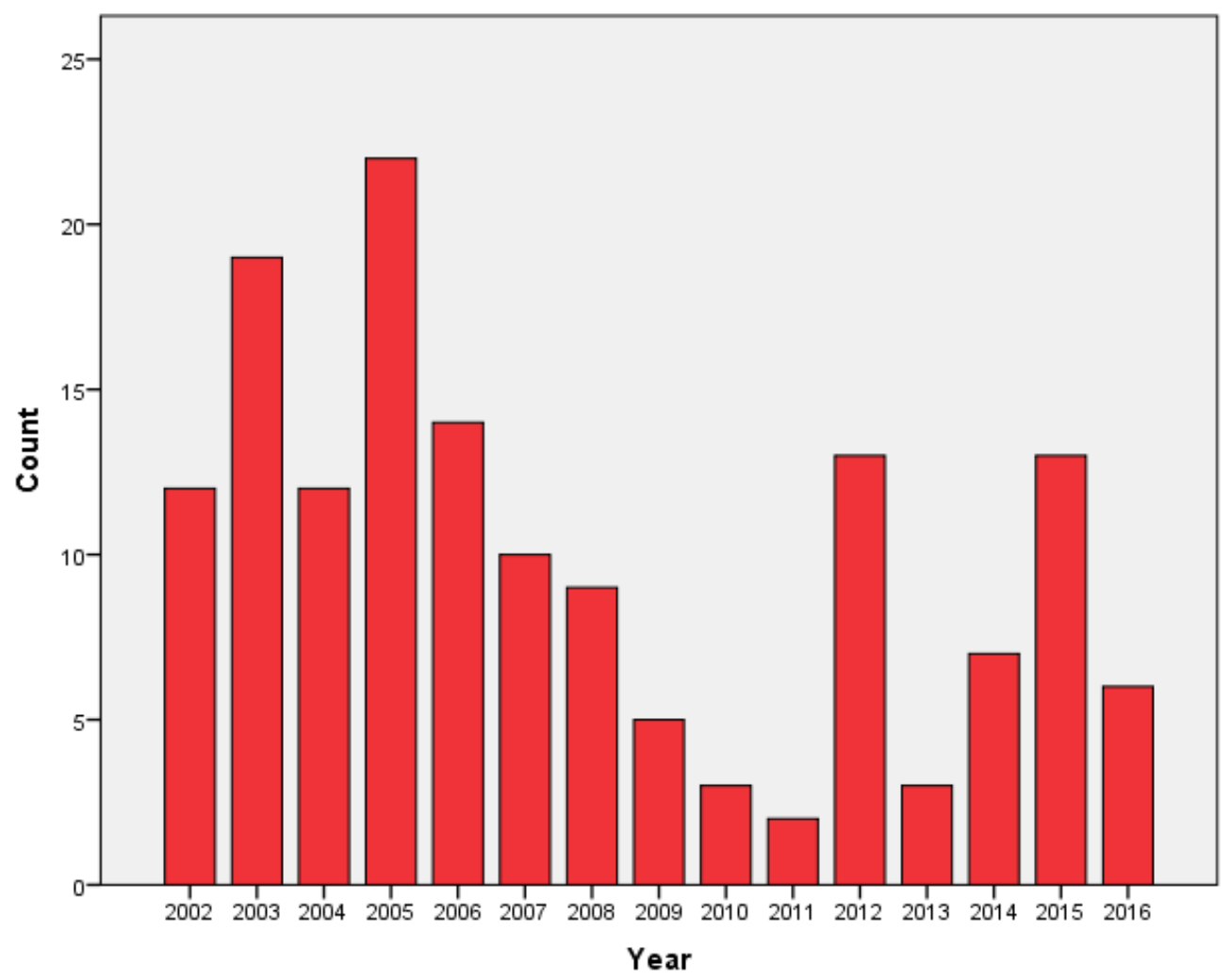

Graph 2: Sum minutes of programmes broadcast to mark HMD

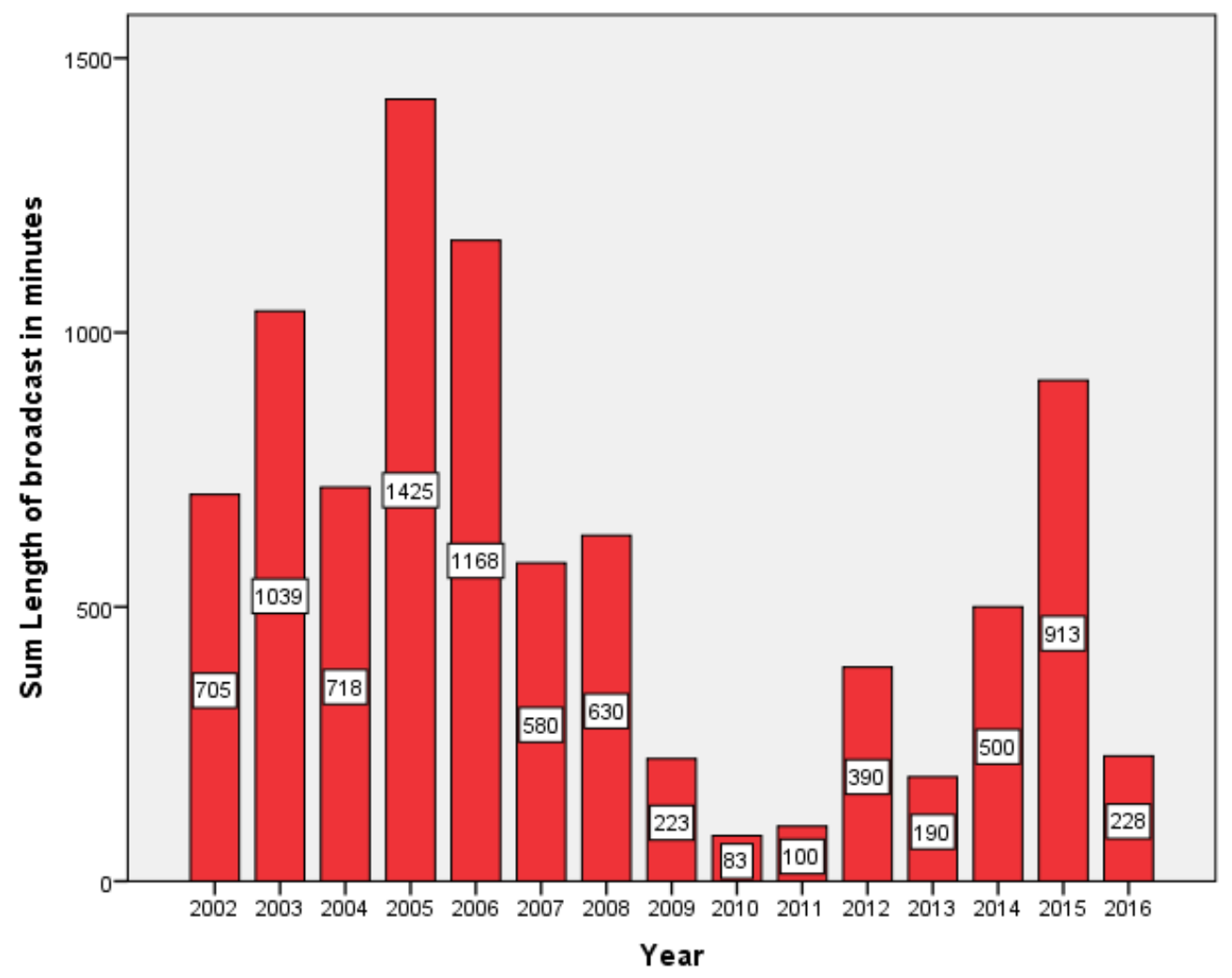


Viewed together, Graphs 1 and 2 reveal a number of clear patterns. First, the frequency and length of programmes broadcast to mark HMD are clustered in two normal-distributions, linked by a fallow period in 2010-11. The 'spike' in the frequency of programmes in 2012 falls outside of this pattern; I discuss the anomaly of this year later in the article. Second, there is some evidence of 'anniversarism' that tends to structure a great deal of public commemoration in the UK, in that the two peaks in the distributions fall in 2005 and 2015, to mark the 60th and 70th anniversaries respectively.

Third, there is an overall decrease in the frequency and length of programmes broadcast over the sample period - the 2015 peak is smaller than the peak in 2005; and the years either side of the 2015 peak were characterised by fewer broadcast texts, and far fewer broadcast minutes, compared with the years either side of 2005. That said, the broadcast minutes in 2006 were skewed by the inclusion of a single extremely long text: the newly established channel More4 broadcast Lanzmann's documentary Shoah in its entirety from $7.10 \mathrm{pm}$ on 21 January to $5.20 \mathrm{am}$ on 22 January. These 610 minutes of programming constitute over half of the sum minutes broadcast to mark HMD that year. Shoah was also broadcast by BBC4 to mark HMD in 2015, though split into two parts: part one was broadcast between $7 \mathrm{pm}-11.25 \mathrm{pm}$ on 25 January, and part two the week after (so falling outside of my sampled week). Without this program, the sum minutes broadcast to mark HMD in 2015 would be brought down to 648 minutes.

At least some of the distribution depicted in Graphs 1 and 2 may be attributable to two factors. Gray and Bell (2013) argue that, by 2006, UK television audiences were feeling "a sense of 'World War II fatigue'"', following the spate of WWII commemoration, starting from the 60th anniversaries of DDay in 2004, through to the 60th anniversary of the liberation of Auschwitz in January 2005 and 60th anniversary of V-E Day and V-J Day in May and August 2005 (see Smither 2004). In addition, and perhaps consequently, there was a shift in the commissioning priorities of the BBC from 2008 onwards, which coincided with the departure of Laurence Rees, the BBC's creative head of history, 
and the disbanding of in-house specialist production teams. Under Martin Davidson, the BBC's new commissioner of specialist factual output, "both money and focus are to be moved away from the second world war, the Nazis and the Holocaust. 'It is time for a change. The well has run dry. We are looking to put the spotlight on other areas'”, says Davidson (Brown 2004). These changes, in both broadcasting institutions and the perceived appetite for Holocaust commemoration in the viewing public appear to have affected the numbers of programmes broadcast.

\section{Quantifying importance}

It should always be born in mind that broadcasting is a commercial medium, where any ambition to commemorate a particular day, or event, will be balanced against considerations of cost, viewing figures and, ultimately, profit. Meyers et al (2014: 131) note that one method that Israeli broadcasters use to reducing costs "is constantly to rerun films and documentaries that were previously aired on Holocaust Remembrance Day." So, to what extent is the British HMD marked by original, or repeat, programming? 


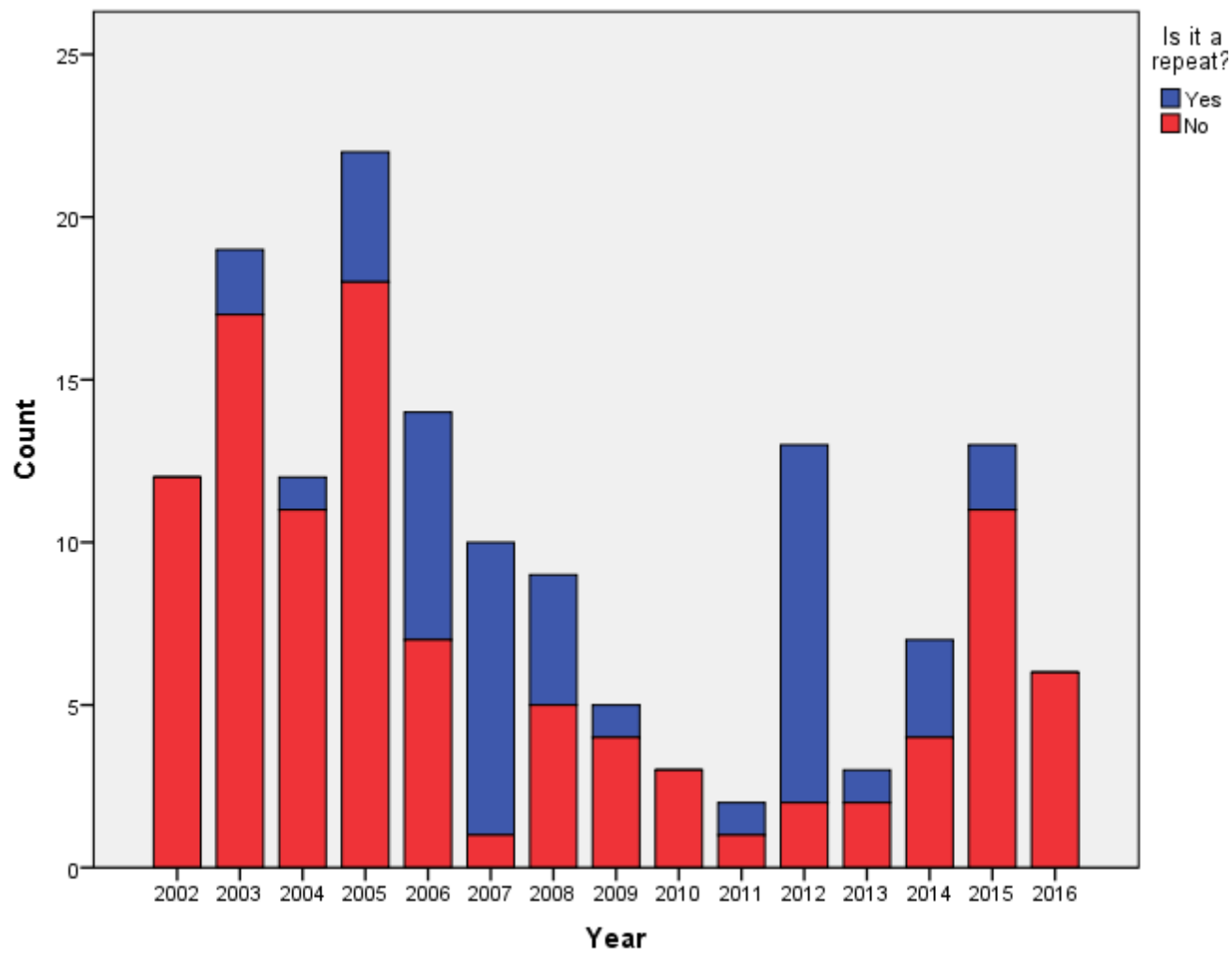

Of the 150 programmes broadcast to mark HMD, 46 (30.7\%) were repeats from previous years.

Although, as I examine below, the BBC infrequently broadcasts documentaries to mark HMD, BBC commissioned documentaries on the Holocaust are repeated on commercial channels - particularly on the channel Yesterday (until 2009 called UKTV History). This relationship is unsurprising of course, given that UKTV History was one of several channels launched in a joint venture between Flextech Television and the BBC, specifically to broadcast repeats of BBC content (Gray and Bell 2013: 43). Taking into account whether a programme was original or a repeat appears to extend the 'fallow period' between the two peaks in 2005 and 2015 - of the 13 programmes broadcast in 2012, only 2 were original, a figure much more in keeping with this period between 2010-2013. The years 20062007, immediately following the significant 60th anniversary year, are also considerably inflated through repeat programming: only one programme broadcast to mark HMD in 2007 was being transmitted for the first time. Graph 3 shows that there were only two years where all programs 
broadcast to mark HMD were original: 2002 and 2016. Methodologically, however, this result is a little questionable; I only quantified the sample period, meaning that some programmes that first appeared in 2002 or 2003 could also have been repeats. That said, Graph 3 above reiterates the general distribution already found, with a large decrease in programming during the middle period.

Graph 4, below, perhaps best represents this pattern, by isolating the sum minutes broadcast of original programming over the 15 years:

Graph 4: Sum minutes of original programming

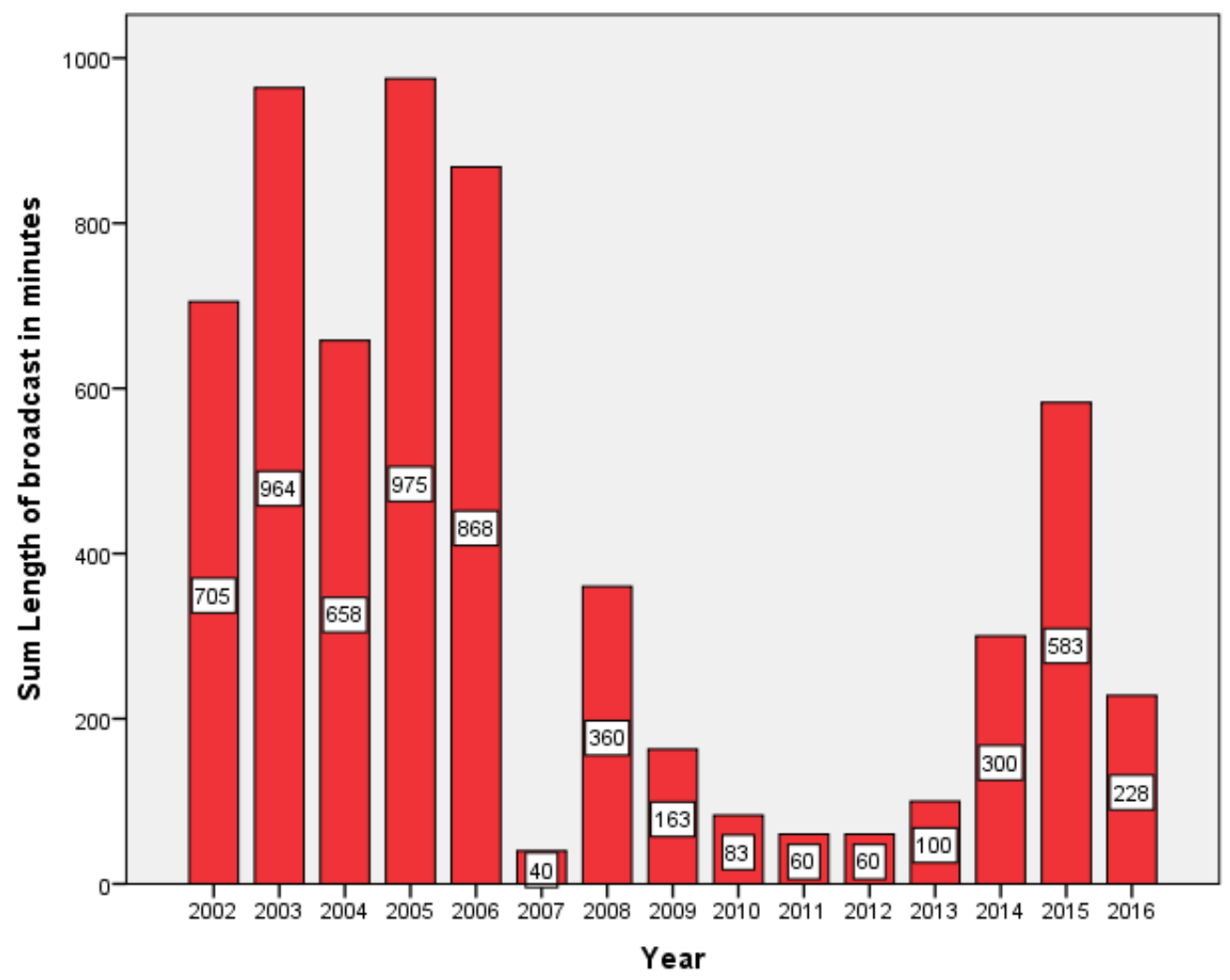

Graph 4 charts the variability of mass mediated commemoration of HMD and, in so doing, reveals the degree to which HMD is not yet integrated into the commemorative calendar of Britain's broadcasters. For four years, between 2009-2013, HMD almost disappeared from the schedules completely, only being acknowledged by broadcasters in a cursory way. 


\section{Broadcaster and genre}

The broadcaster provides an interesting insight into the perceived audience of HMD-relating programming (see Table 1):

Table 1: Broadcaster of HMD-relating programming

\begin{tabular}{|l|c|c|c|}
\hline & \multicolumn{2}{|c|}{ Length of broadcast in minutes } & \\
\hline & Mean & Sum & Total N \\
\hline History Channel/History & 57 & 2340 & 41 \\
\hline Radio4 & 27 & 676 & 25 \\
\hline UKTV History/Yesterday & 44 & 750 & 17 \\
\hline BBC2 & 64 & 1080 & 17 \\
\hline BBC Knowledge/BBC4 & 81 & 1300 & 16 \\
\hline BBC1 & 50 & 755 & 15 \\
\hline Radio2 & 90 & 361 & 4 \\
\hline More4 & 199 & 795 & 4 \\
\hline Radio3 & 70 & 210 & 3 \\
\hline ITV1 & 62 & 185 & 3 \\
\hline Regional ITV & 30 & 30 & 1 \\
\hline Discovery History & 60 & 60 & 1 \\
\hline National Geographic & 210 & 210 & 1 \\
\hline Channel5 & 60 & 60 & 1 \\
\hline Channel4 & 80 & 80 & 1 \\
\hline
\end{tabular}

It is to be expected that The History Channel would be the most frequent broadcaster, however

Table 1 above conceals the fact that their broadcast texts were not distributed evenly across the 15 years. Despite broadcasting 41 of the 103 programmes transmitted between 2002 and 2009, they did not broadcast anything to mark HMD after 2009. Such a stark pattern speaks to a significant change in the channel, either in terms of management or their understanding of their role as a history broadcaster, following their name-change and re-brand in 2008, from The History Channel to, simply, History. Other findings are as revealing. The distribution across BBC TV and radio, for example - Radio 4 marking HMD most frequently, followed by $\mathrm{BBC} 2, \mathrm{BBC} 4$ and then $\mathrm{BBC} 1$ - indicate that the audience for HMD programming is imagined to be a specialised and upper-middle class audience rather than a more general mainstream audience. A similar picture is suggested when comparing the (admittedly low) frequencies on More4 - which brands itself as emphasising 
'intelligent and insightful' programming and attracts predominantly over-35 year old ABC1 audiences (Gray \& Bell 2013) - with its more mainstream channel-mate Channel4.

Aggregating the data for the publicly funded broadcasters (the six BBC TV channels and Radio stations) and those funded by advertising revenue (the remaining 9 channels) reveals a significant difference in their programming choices (see Table 2):

Table 2: Original and Repeat Programming on Publicly and Commercially funded broadcasters

\begin{tabular}{|c|c|c|c|c|c|}
\hline & \multicolumn{4}{|c|}{ Is the programme a repeat? } & \multirow{3}{*}{ Total } \\
\hline & \multicolumn{2}{|c|}{ Yes } & \multicolumn{2}{|c|}{ No } & \\
\hline & $\mathrm{N}$ & Row \% & $\mathrm{N}$ & Row \% & \\
\hline BBC channels & 5 & 6.3 & 75 & 93.7 & $80(100 \%)$ \\
\hline $\begin{array}{l}\text { Commercial funded } \\
\text { broadcasters }\end{array}$ & 41 & 58.6 & 29 & 41.4 & $70(100 \%)$ \\
\hline Total & 46 & 30.7 & 104 & 69.3 & $150(100 \%)$ \\
\hline
\end{tabular}

Table 2 above shows that the vast majority (93.8\%) of programmes broadcast on the BBC to mark HMD were newly produced for that year, whilst commercial broadcasters display a clear preference for repeating cheaper, already broadcast material (58.6\%). A Chi-Square test for this cross-tabulation indicate that the relationship between these variables is statistically highly significant $(p=0.000$ for all tests).

Cross-tabulating genre with these aggregated broadcasters also reveals significant differences between the programming of publicly and commercially funded broadcasters (see Table 3 ): 
Table 3: Genre of programme on Publicly and Commercially funded broadcasters

\begin{tabular}{|l|c|c|c|c|c|}
\hline & \multicolumn{2}{|c|}{ BBC } & \multicolumn{2}{c|}{$\begin{array}{c}\text { Commercial funded } \\
\text { broadcasters }\end{array}$} & Total \\
\hline & $\mathrm{N}$ & Col. \% & $\mathrm{N}$ & Col. \% & \\
\hline Documentary (TV) & 26 & 32.5 & 65 & 92.9 & $91(60.7)$ \\
\hline Religious Programme & 19 & 23.8 & 2 & 2.9 & $21(14.0)$ \\
\hline Documentary (Radio) & 7 & 8.8 & 0 & 0 & $7(4.7)$ \\
\hline $\begin{array}{l}\text { Comment/Thought for the } \\
\text { Day }\end{array}$ & 6 & 7.5 & 0 & 0 & $6(4.5)$ \\
\hline Docudrama (TV) & 5 & 6.3 & 1 & 1.4 & $6(4.5)$ \\
\hline $\begin{array}{l}\text { Concert/Musical } \\
\text { Performance }\end{array}$ & 4 & 5.0 & 0 & 0 & $4(2.7)$ \\
\hline Talk Show & 4 & 5.0 & 0 & 0 & $4(2.7)$ \\
\hline Televised Ceremony & 3 & 3.8 & 1 & 1.4 & $4(2.7)$ \\
\hline Magazine Programme & 3 & 3.8 & 0 & 0 & $3(2.0)$ \\
\hline Docudrama (Radio) & 2 & 2.5 & 0 & 0 & $2(1.3)$ \\
\hline Debate Show & 1 & 1.3 & 0 & 0 & $1(0.7)$ \\
\hline Feature film & 0 & 0 & 1 & 1.3 & $1(0.7)$ \\
\hline & & & & & \\
\hline Total & 80 & 100 & 70 & 100 & $150(100)$ \\
\hline
\end{tabular}

Table 3 shows that the national HMD ceremony was only broadcast four times during the sample period - on the BBC in 2005, 2015 and 2016, and an abridged version of the 2002 ceremony (cut down from over an hour to 24 minutes) broadcast on Regional ITV. This pattern of commissioning therefore exemplifies the anniversarism that structures the whole distribution, where the 60th and 70th anniversaries were more emphatically commemorated. The Chief Executive of the Holocaust Memorial Day Trust (HMDT) confirmed this ${ }^{4}$ :

2005, I thought that they broadcast it because it was the sixtieth anniversary, and that created a sufficient hook for it to be worth the BBC broadcasting it. 2015, the same, we went to the $\mathrm{BBC}$ and asked if they were prepared to broadcast it and, yes, they were very keen to because it was marking the seventieth anniversary.

The success of the 2001 and 2015 broadcasts also engendered a 'commemorative echo' the years that immediately followed, ${ }^{5}$ but, with diminishing audiences, subsequent ceremonies in 2003 and 2017 were not broadcast. As the Chief Executive of HMDT suggests: 
The viewing figures for 2015 were 1.3 million, and when we approached them and said do they want to work with us again to broadcast it in 2016, I think the reasons they had were partly the high viewing figures made them want to do it again, and the theme for 2016 of 'Don't Stand By', they really liked the theme. [...] 2016, the viewing figures were half a million, five hundred thousand, and the reason they didn't want to broadcast it again in 2017 were largely financial, because the BBC budget was under a massive amount more pressure, and the viewing figures weren't over the million mark, which would have given them more of a push to be doing it. ${ }^{6}$

Therefore, in the case of a public service broadcaster like the BBC, pseudo-commercial motivations shape programming decisions, with the costs of commissioning and producing programmes weighed against the potential size of the audience.

Table 3 demonstrates that documentary films are the predominant way that commercially funded broadcasters mark HMD, whilst the programming of the $B B C$ is far more varied. Of the 46 repeat programmes broadcast to mark HMD, 42 (91.3\%) were documentaries; these 42 repeats represented $46.2 \%$ of all documentary texts broadcast over the sample period $(n=91)$. To pull this together, there are therefore two significant relationships between these three variables: commercial broadcasters are significantly more likely to broadcast documentaries rather than other genres; and documentaries are significantly more likely to be repeats. Chi-square tests reveal that the relationships between these variables was statistically significant $(p=0.000$ for both Table 3 , above, and cross-tabulating 'genre of broadcast' * 'is the programme a repeat').

In contrast to the commercial funded broadcasters, $58.7 \%$ of programmes broadcast in the BBC to mark HMD were not documentaries (on either TV or Radio). One perhaps surprising genre in Table 3 is the concert/musical performance. Examples broadcast on the BBC included Les Arts Florissants, the first of four programmes broadcast on BBC4 as part of their Holocaust Memorial season (26 January 2003, 7.05pm-9.05pm), We want the light (BBC2, 25 January 2004, 7.00pm-8.00pm) 
exploring "the importance of music in the integration of Jews into German cultural life", and Holocaust - a Music Memorial Film from Auschwitz (BBC2, 22 January 2005, 9.00pm-10.30pm) which "reflects on the Nazis' use of music as a psychological tool in Auschwitz". This programme, "a BBC/ZDF/CBC/TVP (Poland)/ CT (Czech Republic) co-production, won an international Emmy for its combination of musical performance and survivor testimony for producer James Kent and executive producer Peter Maniura, the BBC Head of Classical Music Television" (Gray \& Bell 2013: 116). Other programmes also centred on music, including Burnside's radio show (BBC3, 27 January 2008, 10.0012 noon) in which he and "musicologist Erik Levi explore some of the music the Nazis banned, some they appropriated to their cause, and some that emerged in opposition to their regime". These programmes foreground the mnemonic work of music as both an emotive soundtrack to catastrophe (cf Neiger et al 2011a) and as a way of exploring other topics - music as a symbol of humanity, the presence of music in concentration camps and/or as an instrument of Nazi oppression, or as a means of exploring what was lost and what remains.

Another striking finding in Table 3 is the large number $(n=19 ; 23.8 \%)$ of Christian religious programmes broadcast on the BBC (including Songs of Praise, The Heaven and Earth Show and Radio4's Sunday Worship), compared to only two (2.9\%) broadcast on commercial channels (two instances of My Favourite Hymn on ITV1). To mark the 2005 HMD, for example, a special edition of Songs of Praise was aired, "in which sixth-form students were accompanied on their journey to Auschwitz and discussed their reasons for wishing to visit [...] the Holocaust Educational Trust [...] were involved in the episode" (Gray \& Bell 2013: 117).

This volume of religious programming perhaps shows the rhetorical bleed between religious and secular commemoration - religion, after all, has a readymade vocabulary and liturgy for dealing with death and commemorative rites. However, are there any ideological implications of these mainly Christian programmes commemorating Jewish victims? Further, are there any implications of commemorating the Shoah through a general religious, rather than a specifically Jewish, frame of 
reference? On this point, it is interesting to note that during WWII, "'the Jewish Issue' was seen to some extent by the BBC as a 'political' problem" (Seaton 1987: 70), and that - despite the Allied Declaration on the fate of Jewry, 17 December 1942, which confirmed the veracity of information previously received, regarding mass exterminations of Jewish civilians - "it was felt within the BBC that to single out 'Jews' for special mention, was in itself uncivilized" (Ibid). In place of iterating the particularity of Nazi antisemitism, the BBC opted to emphasise the war as an affront to universal moral values. Accordingly:

Sidney Silverman, the prominent Jewish MP, was thus advised to pursue his case in moral and religious terms, because the $\mathrm{BBC}$ could be more sympathetic to this kind of appeal. Indeed, various Jewish organizations already, by the beginning of 1942, had begun to make approaches to the Religious Broadcasting section of the Corporation, and within the subsequent three years, religious broadcasting was one of the main focuses of Jewish pressure [...] to make clearer to the British audience the nature of the fate of Jews in Europe. (Seaton 1987: 71-72)

The question of whether the Holocaust is a universal tragedy or a particular one is, of course, a significant issue in the historiography of the Holocaust. This question deserves to be looked at in more qualitative detail, with specific reference to the historical and commemorative work accomplished by the BBC's religious (Christian) programmes.

\section{'Commemorative commonplaces'}

Whilst conducting my primary data collection, photographing HMD-related programmes in the Radio Times, there appeared to be an emphasis on certain 'commemorative commonplaces' in the topics and stories included in the programmes and the ways they were described. Quantifying these, I found that $32 \%(n=48)$ of the programmes mentioned Auschwitz in their titles or programmes 
descriptions - a figure which seems to support the argument of people like Cole (2000) that Auschwitz has become the defining metonym of the Holocaust. Other death camps were mentioned in only $7.3 \%(n=11)$ of programmes, and other concentration camps referred to in $14 \%(n=21)$. Of the thousands of concentration camps and satellite camps, only Bergen-Belsen and Terezin/Theresienstadt were mentioned with any frequency. The Einsatzgruppen, Einsatzkommandos and mass murder of civilians and 'partisans' in countries to the East of occupied Poland, by both Nazi soldiers and their local accomplices, were not specifically referred to in any title or programme description in the Radio Times. Nor were any topics or periods of time referred to that called into doubt Britain's wartime record - the Occupation of the Channel Islands, for example, or Anthony Eden's refusal to issue visas to Jews trying to flee Vichy France.

Surprisingly, perhaps, Oskar Schindler was mentioned in only $4 \%(n=6)$ of programmes, Nicholas Winton in $2.7 \%(n=4)$ and Anne Frank in $2 \%(n=3)$. However, children were mentioned in $12.7 \%(n=$ 19), music was mentioned in $17.3 \%(n=26)$ and survivors were mentioned in $34 \%(n=51)$ of programme titles or descriptions. Often these commemorative commonplaces were combined children and survivors were frequently linked, which makes sense given that all Holocaust survivors during the period under analysis were only children during WWII. Other combinations spoke instead to preferences for stories of survival that also allowed programme makers to explore a musical motif - for example, the documentary Everything is a present examines the life of "concentration camp survivor and concert pianist Alice Herz-Sommer" (BBC4, 27 January 2010, 8.00pm-8.50pm, repeated BBC2, 27 January 2011, 11.20pm-00.10am).

The numbers of programmes broadcast in some years is small, and so it is difficult to offer conclusions on the statistical significance of these 'commemorative commonplaces'. However, there does appear to be a small increase in the proportion of programmes which the Radio Times describes as featuring survivors: for each of the final 4 years of the sample (2013-16, inclusive) there were more programmes described as featuring survivors than were not; there were only two other 
years in the sample where this happened (2004 and 2007), suggesting an increasing focus on stories of survival rather than (or, perhaps, in parallel to) stories of extermination.

Whilst, clearly, any stories of survival are heartening, the emphasis placed on survival, by programme makers and broadcasters, at points seems to pay undue attention to such cases. The one programme broadcast in my sample featuring Treblinka, for example (Death Camp Treblinka, BBC4 27 January 2016, 10.00pm-11.00pm), placed far greater emphasis on "how Samuel Willenberg and Kalman Taigman escaped" than on the $870,000-925,000$ Jews that were murdered in the Treblinka II killing centre. In addition, we should always be attuned to whose survival is featured in HMD-related programming, and so whose story is told, given that "by and large, the protagonists who dominate the broadcasts are Holocaust survivors who can emblem the 'right' story bearing the 'right' lessons; in most cases, this requirement is translated into the accounting of redemptive narratives of survivors who have overcome the trauma" (Meyers et al 2014: 156-57). These issues also demand further detailed qualitative analysis.

\section{Conclusion}

This article has examined programmes broadcast on British television and radio to mark Holocaust Memorial Day. I sampled one week of broadcasting, on television and radio, around the week of HMD for fifteen years (2002-2016). My content analysis shows that the frequency of broadcasting was distributed in two normal-distributions, with peaks in outputs during the anniversary years of 2005 and 2015. During the fallow period in between these peaks, broadcasting dipped as low as 40 minutes of original HMD commemorative programming in 2007 and 60 minutes in both 2011 and 2012. The national ceremony was only broadcast four times during the sample period, in 2002,2005 , 2015 and 2016, which is a great shame given that this event, more than any other broadcast text, communicates shared values in addition to Holocaust history (Richardson 2018b). I found significant differences between the scheduling of the BBC and commercial broadcasters. The outputs of the 
BBC were far more diverse, including a wide range of broadcast genres, and comprised far fewer repeat broadcasts; commercial broadcasters, on the other hand, marked HMD almost entirely with documentaries, the majority of which were repeats.

Institutional changes in key broadcasters appear to be the reason for this decline in coverage of HMD. The History Channel re-branded in 2008 and did not broadcast a single programme to commemorate HMD between 2009-2016; in the BBC, Laurence Rees departed as creative head of history, replaced by Martin Davidson as the commissioner of specialist factual output, and in-house specialist production teams were disbanded. These changes were accompanied by a perceived 'war fatigue' on the part of the viewing public (Gray \& Bell 2013) and an editorial decision to favour commissioning history examining other subjects.

I stress that my sample only covers the week of successive HMDs, and not the mass-mediation of the Holocaust across the remainder of the year. However, whilst it may indeed be the case that the Holocaust has become a foundational event in Western culture and society, quantitative analysis of the mass mediation of Holocaust Memorial Day suggests that marking this day has not yet become established in the commemorative calendar of British broadcasters.

\section{Acknowledgement}

This research was funded by a Leverhulme Trust Research Fellowship. I gratefully acknowledge this support.

\section{References}

Allwork, L. (2015) Holocaust Remembrance between the National and the Transnational: The Stockholm International Forum and the First Decade of the International Task Force. London: Bloomsbury Academic 
Bennett, T. (2006) Distinction on the box: cultural capital and the social space of broadcasting, Cultural Trends 15(2-3): 193-212

Brown, M. (2008) The end of an era, Guardian 10 November 2008, available at https://www.theguardian.com/media/2008/nov/10/bbc-history-programmes [accessed 9 May 2017]

Chapman, J. (2007) Re-presenting War: British Television drama-documentary and the Second World War, European Journal of Cultural Studies, 10(1): 13-33

Cole, T. (2000) Selling the Holocaust: From Auschwitz to Schindler, How History is bought, packaged and sold. New York: Routledge

Corner, J. (1999) Critical Ideas in Television Studies. Oxford: Oxford University Press

De Groot, J. (2016) Consuming History: Historians and Heritage in Contemporary Popular Culture. Oxon/New York: Routledge

Dillon, R. (2010) History on British Television: Constructing Nation, Nationality and Collective Memory. Manchester: Manchester University Press

Eadson, W., Pearson, S., Foden, M., Sanderson, E. \& Bashir, N. (2015) Holocaust Memorial Day Impact Study: Final Report. Sheffield: Centre for Regional Economic and Social Research (CRESR) Sheffield Hallam University

Edgerton, G. R. \& Rollins, P. C. (2001) (eds.) Television Histories: Shaping Collective Memory in the Media Age. Lexington: University Press of Kentucky

Ellis, J. (2000) Scheduling: the last creative act in television? Media, Culture and Society, 22(1): 25-38

Fraser, D. (2000) The Jews of the Channel Islands and the Rule of Law, 1940-1945. Eastbourne:

Sussex Academic Press

Gray, A. \& Bell, E. (2013) History on Television. New York/Oxon: Routledge 
Holmes, S. (2005) British TV and Film Culture in the 1950s. Bristol: Intellect Books

Jacobs, J. (2000) The Intimate Screen: Early British Television Drama. Oxford: Oxford University Press Johnson, C. (2007) Negotiating value and quality in television historiography, in $\mathrm{H}$. Wheatley (ed.) Reviewing Television History: Critical Issues in Television Historiography, pp. 55-66. London: IB Tauris Kansteiner, W. (2006) In Pursuit of German Memory: History, Television, and Politics after Auschwitz. Athens: Ohio University Press

Kansteiner, W. (2008) Sold Globally - Remembered Locally: Holocaust Cinema and the Construction of Collective Identities in Europe and the US, in Berger, S., Eriksonas, L. \& Mycock, A. (eds) Narrating the Nation: Representations in History, Media and the Arts, pp.153-180. New York \& Oxford: Berghahn Books Kershaw, I. (2004) The Past on the Box: Strengths and Weaknesses, in Cannadine, D. (ed.) History and the Media, pp.118-123. Houndmills: Palgrave

Kitch, C. (2005) Pages from the Past: History and Memory in American Magazines. Chapel Hill, NC: University of North Carolina Press

Lebow, R. N. (2006) The Memory of Politics in Postwar Europe, in Lebow, R.N., Kansteiner, W. \& Fogu, C. (eds.) The Politics of Memory in Postwar Europe, pp.1-39. Durham \& London: Duke University Press

Macdonald, S. (2005) Commemorating the Holocaust: Reconfiguring National Identity in the TwentyFirst Century, in Littler, J \& Naidoo, R. (eds) The Politics of Heritage: The Legacies of 'Race', pp.49-68. Oxon: Routledge

Marrus, M. R. (2015) Lessons of the Holocaust. Toronto: University of Toronto Press 
Meyers, O., Zandberg, E. \& Neiger, M. (2009) Prime Time Commemoration: An Analysis of Television Broadcasts on Israel's Memorial Day for the Holocaust and the Heroism, Journal of Communication 59: $456-480$

Meyers, O., Zandberg, E. \& Neiger, M. (2014) Communicating Awe: Media Memory and Holocaust Commemoration. Houndmills: Palgrave

Neiger, M., Meyers, O. \& Zandberg, E. (2011a) Tuned to the nation's mood: Popular music as a mnemonic cultural object, Media, Culture \& Society: 33(7): 971-987

Neiger, M., Meyers, O. \& Zandberg, E. (eds) (2011b) On Media Memory: Collective Memory in a New Media Age. London: Palgrave Macmillan

Pearce, A. (2013) Britain's Holocaust Memorial Day: Inculcating 'British' or 'European' Holocaust Consciousness?, in Sharples, C. \& Jensen, O. (eds.) Britain and the Holocaust Remembering and Representing War and Genocide pp.190-211. Houndmills: Palgrave

Pearce, A. (2014) Holocaust consciousness in contemporary Britain. London: Routledge

Piccini, A. (2007) A survey of heritage television viewing figures, Council for British Archaeology available at http://new.archaeologyuk.org/Content/downloads/4300 Research Bulletin Number 1 final.pdf [accessed 19 May 2017]

Richardson, J.E. (2017) Making memory makers: Interpellation, norm circles and Holocaust Memorial Day Trust workshops. Memory Studies iFirst 1-18.

Richardson, J.E. (2018a) Sharing values to safeguard the future: British Holocaust Memorial Day Commemoration as Epideictic rhetoric. Discourse \& Communication iFirst 1-21 DOI: 
Richardson, J.E. (2018b) Mediating National History and Personal Catastrophe: Televising Holocaust Memorial Day commemoration. Fudan Journal of Humanities and Social Science iFirst DOI:

$10.1007 / \mathrm{s} 40647-017-0209-4$

Sauer, C. (2012) Multimodality and performance: Britain's first Holocaust Memorial Day, in L.N.

Berlin \& A. Fetzer (eds) Dialogue in Politics, pp.241-307. Amsterdam: John Benjamins

Scannel, P. \& Cardiff, D. (1991) A Social History of British Broadcasting, 1922-1939. London: Wiley-

Blackwell

Seaton, J. (1987) The BBC and the Holocaust, European Journal of Communication 2: 53-80

Shandler, J. (1999) While America Watches: Televising the Holocaust. Oxford: Oxford University Press

Smither, R. (2004) Why is so much Television History about War? In Cannadine, D. (ed.) History and

the Media, pp.51-66. Houndmills: Palgrave

Stone, D. (2012) (ed.) The Holocaust and Historical Methodology. New York/Oxford: Berghahn Books

Young, J. (1999) America's Holocaust: Memory and the Politics of Identity, in Flanzbaum, H. (ed.) The

Americanization of the Holocaust, pp.68-82. Baltimore

Zelizer, B. (1992) Covering the body: The Kennedy assassination, the media, and the shaping of collective memory Chicago: University of Chicago Press.

\footnotetext{
${ }^{1}$ Certainly Meyers et al (2014: 97) argue that "[...] the ceremonies, dramas, documentaries and newscasts aired by Israeli television channels on Holocaust Remembrance Day offer the most heavily attended mnemonic public events of that day."

${ }^{2}$ Lebow (2006), for example, argues that for Britain, WWII doesn't represent "a past at once threatening and at odds with the general thrust of postwar identity construction", nor did Britain have to deny "any national responsibility for the Holocaust", because Britain "was never occupied" (p.31).

${ }^{3}$ The BBC religious programme Songs of Praise, for example, is only ever broadcast on a Sunday; on years where HMD fell close to Sunday, the programme was orientated to the commemoration of the Holocaust.

${ }^{4}$ Interview with author, 18 May 2017.
} 
${ }^{5}$ The 2005 broadcast was also a success, but the national ceremony was not broadcast in 2006 - presumably as a result of the commemorative "fatigue" described by Gray and Bell (2013), following "saturating the schedules" with war commemoration between 2004-2005, "to such a degree that audience members no longer wish to watch" (p.114).

${ }^{6}$ Interview with author, 18 May 2017. 